\title{
Editorial
}

\section{An Editor's review: the past year and the one ahead for SAJBS}

About the Journal in the last year

Eight years since its inception, South Asian Journal of Business Studies (SAJBS) has published research in areas ranging from marketing, finance, leadership, organizational studies and more. $S A J B S$ is currently listed in the ABDC Journal Quality List as well as the Emerging Journal Citation Index; and in 2019 received an official ranking from Scopus. Despite the short life span, the increasing, downloads and citations ( 0.76 per published article) along with an h-index of 4.00 are a sign of the journal's increasing relevance. Moreover, $\mathrm{ABDC}$ is in the process reviewing of their journal rankings later in 2019 and we have applied for an upgrade in our ranking.

Table I provides a breakdown of the focus areas of the 20 papers published in Volume 8 in - five in finance, trade and economics, three in marketing, three in organization theory and strategy, three in sustainability and corporate social responsibility, two in organization behavior and four from a special section on "Entrepreneurship, Creativity and Innovation." This is the second special section in my editorial term. The first special issue in 2017 explored "Gender and Leadership."

The papers published in 2018-2019 were downloaded 21,165 times, three times more than the number of downloads in 2014. In this Editorial, we provide an overview of Volume 8, a brief summary of the papers in the latest issue (Issue 3 ) followed by the journal's prospects. The aim of this volume like the ones before it was to bring awareness to the readers on current research and business trends in the South Asian context. Table II provides information on countries that the studies were based on and their focus - single vs multi-country. From a quick review of Table II we see that 16 were single-country studies while the remaining four were multi-country. All countries within the journal's geographic scope were represented in Volume 8, however, we have published/accepted more papers from India and Pakistan.

\section{Topics covered in 2019}

In Volume 8 Issue 1, six papers published broadly focused on the following areas - customer equity, commercialization of innovations, impact of trade and financial openness on loan delinquencies, corporate distress and its impact on debt restructuring, a review of Management research over the last 25 years, and finally the impact of the carbon supply chain on environmental sustainability.

In the second issue, we published five papers - two in organizational management, and one each in finance, economics and marketing. The management papers examined: the effect of organizational politics on job outcomes, and the impact of board characteristics on the governance structure of firms. The finance and economics papers explored the impact of real exchange rates volatility on exports, and the effects of bank competition on economic growth. The marketing paper provided insights on how the Indian notion of "cool" was different from the western perspective.

\section{About the papers in the current issue}

The current issue consists of a total of nine papers. Five were accepted for the regular issue of $S A J B S$ and four are from the special section on entrepreneurship, creativity and innovation. The five papers include one each in marketing, finance and entrepreneurship as well as two in the areas of CSR and sustainability.

The marketing paper focuses on transformation of shopping from traditional stores to online shopping. The research was conducted in Pakistan to assess the service quality of

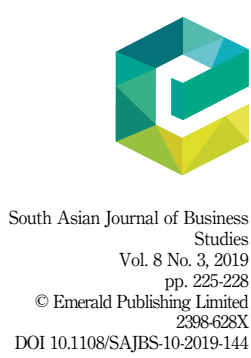


SAJBS

8,3

Table I.

Summary of papers

in Volume 8 by disciplinary areas e-stores that are available in the country. The findings indicate that the quality of online shopping experience relates to customer satisfaction and customer loyalty (Khan et al., 2019). The second paper examines the relationship between trade balances, exchange rates and interest rates on stock prices. The study finds that macroeconomic variables play a significant role in taking investment and policy decisions (Chang et al., 2019).

The next two papers look at the relationship between corporate social responsibility and two different outcome variables - financial performance and organizational citizenship behavior. While the first paper demonstrates that third party assurance negatively mediates the CSRperformance relationship in a sample of Indian firms (Oware and Mallikarjunappa, 2019), the second paper finds that organizational pride positively mediates the CSR-citizenship relationship in a sample of Pakistani firms in the hospitality industry (Hameed et al., 2019).

The final paper analyzes the relationship of entrepreneurial orientation and organizational culture on behavioral outcomes such as job satisfaction, organizational commitment, and employee performance (Soomro and Shah, 2019). In addition to these five papers, we have four papers that are part of a special section on entrepreneurship, creativity and innovation. The four papers are in presented in Table III and more about these papers are discussed in Guest Editorial.

\begin{tabular}{lc} 
Disciplinary area & No. of papers \\
\hline Marketing & 3 \\
Finance and economics & 5 \\
Organization theory and strategy & 3 \\
Organizational behavior & 2 \\
Environmental sustainability & 3 \\
Entrepreneurship, creativity and innovation (Special Section) & 4
\end{tabular}

\begin{tabular}{|c|c|c|c|c|}
\hline$\underline{\text { Disciplinary area }}$ & Focal country/(ies) & $\begin{array}{l}\text { Single } \\
\text { country }\end{array}$ & $\begin{array}{l}\text { Multiple } \\
\text { country }\end{array}$ & Total \\
\hline Marketing & India, Malaysia and Pakistan & 2 & $1^{\mathrm{a}}$ & 3 \\
\hline Finance and Economics & $\begin{array}{l}\text { India, Pakistan, Sri Lanka, Bangladesh, } \\
\text { Afghanistan, and Nepal }\end{array}$ & 3 & $2^{\mathrm{b}}$ & 5 \\
\hline $\begin{array}{l}\text { Organization Theory and } \\
\text { Strategy }\end{array}$ & $\begin{array}{l}\text { India, Pakistan, Afghanistan, Bangladesh, } \\
\text { Bhutan, Maldives, Nepal and Sri Lanka }\end{array}$ & 2 & $1^{\mathrm{c}}$ & 3 \\
\hline Organizational Behavior & Pakistan & 2 & - & 2 \\
\hline Environmental sustainability & India and Pakistan & 3 & - & 3 \\
\hline \multirow{2}{*}{$\begin{array}{l}\text { Entrepreneurship, Creativity, and } \\
\text { Innovation (Special Section) }\end{array}$} & India and Nepal & 4 & - & 4 \\
\hline & Total & 16 & 4 & 20 \\
\hline
\end{tabular}

Table II.

Papers with the country of focus (single-country/multicountry) based on the disciplinary area
Notes: aMalaysia and Pakistan; ${ }^{b}$ Pakistan, Bangladesh, India and Sri Lanka; Pakistan, Bangladesh, India and Sri Lanka, Afghanistan and Nepal; 'India and Pakistan
Table III.

Papers in the special section: "Entrepreneurship, Creativity, and Innovation"

\section{Title of the manuscript \\ Author}

When do entrepreneurial firms benefit from transactive memory systems?

Batra and Dey (2019) Entrepreneurial leadership and business performance: effect of organizational $\quad$ Paudel (2019) innovation and environmental dynamism Implications of strategic flexibility in small firms: the moderating role of absorptive capacity Chaudhary (2019) Getting even: a study of abusive supervision, workplace deviance and intention to quit Pradhan and Jena in Indian entrepreneurial organizations
(2019) 


\section{Conclusion}

The mission of $S A J B S$ has been to advance theoretical and empirical learning around issues faced by both multinational and local organizations in South Asia and by the South Asian diaspora. We see some emerging trends that mirror western values and some that have a uniquely South Asian identity. For example, the need to balance economic growth with more sustainable business practices, a greater desire for transparency from organizations and the emergence of a more egalitarian culture in the workforce are moving South Asia closer to the global values and practices. (Gopalakrishnan, 2016).

With these prospects in mind, we would like to provide an opportunity for scholars interested in themes relevant to the region to present their work in our journal. The journal continues to be interested in work that looks at management ideas in South Asia and how they differ across countries in the region. With that in mind we have also commissioned three additional special issues - one on work-family balance and the second on new social media marketing strategies followed by the third on positive organizational scholarship. The aim of these special issues is to encourage scholars to explore these topics in the context of South Asia for unique perspectives that the region brings to global scholarship.

\section{Shanthi Gopalakrishnan}

\section{References}

Batra, S. and Dey, A.K. (2019), "When do Entrepreneurial Firms benefit from transactive memory systems?", South Asian Journal of Business Studies, (forthcoming).

Chang, B.H., Meo, M.S., Syed, Q.R. and Abro, Z. (2019), "Dynamic Analysis of the relationship between stock prices and macroeconomic variables: an empirical study of Karachi Stock Exchange", South Asian Journal of Business Studies, Vol. 8 No. 3, pp. 291-307.

Chaudhary, S. (2019), "Implications of strategic flexibility in small firms: the moderating role of absorptive capacity", South Asian Journal of Business Studies, Vol. 8 No. 3, pp. 258-274.

Gopalakrishnan, S. (2016), “An editorial”, South Asian Journal of Business Studies, Vol. 6 No. 1, pp. 2-7.

Hameed, Z., Khan, I.U., Islam, T., Sheikh, Z. and Khan, S.U. (2019), “Corporate social responsibility and employee pro-environmental behaviors: the role of perceived organizational support and organizational pride", South Asian Journal of Business Studies, Vol. 8 No. 3, pp. 308-327.

Khan, M.A., Zubair, S.S. and Malik, M. (2019), “An assessment of E-Service quality, E-Satisfaction and E-Loyalty: case of online shopping in Pakistan”, South Asian Journal of Business Studies, Vol. 8 No. 3, pp. 345-364.

Oware, K.M. and Mallikarjunappa, T. (2019), "Corporate social responsibility investments, third-party assurance and firm performance in India: the moderating effect of Financial Leverage", South Asian Journal of Business Studies, (forthcoming).

Paudel, S. (2019), "Entrepreneurial leadership and business performance: effect of organizational innovation and environmental dynamism", South Asian Journal of Business Studies, Vol. 8 No. 3, pp. 236-257.

Pradhan, S. and Jena, L.K. (2019), "Getting even: a study of abusive supervision, workplace deviance and intention to quit in Indian entrepreneurial organizations", South Asian Journal of Business Studies, Vol. 8 No. 3, pp. 275-290.

Soomro, B.H. and Shah, N. (2019), "Determining the impact of entrepreneurial orientation and organizational culture on job satisfaction, organizational commitment, and employee performance", South Asian Journal of Business Studies, Vol. 8 No. 3, pp. 328-344. 
SAJBS

8,3

228

\section{About the editor}

Dr Shanthi Gopalakrishnan is Professor at the School of Management, at NJIT, New Jersey. She received her PhD Degree in Organization Management from Rutgers University. Her research interests are in the area of innovation management, knowledge management, leadership, vendor-client relations and strategic alliances. She has published over 50 articles on these topics in journals such as Journal of Management Studies, IEEE Transactions in Engineering Management, Industrial Marketing Management and Journal of Business Research. Dr Gopalakrishnan is Editor-in-Chief of the South Asian Journal of Business Studies, and was Past President and Fellow of Eastern Academy of Management. She also serves on the advisory board of Organization Management Journal and Editorial Board of Journal of Strategic Management. 